\title{
Microclimate Control in Greenhouses
}

Nemanja Radojević

MSc Automation Engineering

Politecnico di Milano, Milan

Italy

\section{Danka Kostadinović}

MSc University of Belgrade Faculty of Mechanical Engineering

Hristina Vlajković

MSc University of Belgrade Faculty of Mechanical Engineering

Emil Veg

MSc University of Belgrade Faculty of Mechanical Engineering
The main reason for applying microclimate control in greenhouses is to achieve optimal growing environment. Because of its complexity, excessive control in greenhouses can adversely affect the growing crops. Moreover, we need an optimal ambiental control to accomplish these complicated objectives, including low emissions and reduced production costs. This paper describes one practical approach to the real-time control system in a greenhouse. Control system considers internal and external ambient factors related to the regulation process. Control system cyclically reads the data from the sensors and implements appropriate response on the actuator, based on required greenhouse conditions. Most challenging was the design of the control algorithm for this kind of process, due to a complexity of influential greenhouse variables

Keywords: greenhouse climate control, greenhouse plant, optimal envitoment, real-time system.

\section{INTRODUCTION}

In order to achieve optimal plant growth and maximize the yield, microclimate in greenhouses should be closely monitored by an advanced mechatronic systems. According to the intrinsic greenhouse features, the setting and tuning of greenhouse climate controllers is by no means an easy or standard procedure. A large number of greenhouse controller settings makes it difficult to foresee its influence on the results and the costs involved. One uses an optimal control to reach the resulting complex production system [1]. The dynamic behavior of the greenhouse microclimate is a combination of physical processes involving energy transfer (radiation and heat) and mass balance (water vapor fluctuation and $\mathrm{CO}_{2}$ concentration). These processes depend on the environmental conditions, structure of the greenhouse, type and state of the crop, and on the effect of the control actuators [2].

The main reason for microclimate control in greenhouses is to achieve maximum plant growth and yield.

Automatic control system monitors:

- inside the greenhouse (soil and air temperature, relative humidity, carbon dioxide concentrations, electrical conductivity and soil moisture)

- $\quad$ outside the greenhouse (temperature, relative humidity, solar radiation, wind speed, wind direction and rainfall rate)

- $\quad$ equipment

(pipe temperature, vents and curtains position)

Each microclimate parameter should be maintained at optimal level, which is determined by a type and state of the crop [3]. Location and sensor numbers depend on

Received: December 2012, Accepted: February 2014

Correspondence to: Nemanja Radojevic

Politecnico di Milano

Milan, Italy

E-mail: nemanjaradojevic@gmail.com

doi:10.5937/fmet1402167R

(C) Faculty of Mechanical Engineering, Belgrade. All rights reserved the structure and dimensions of the greenhouse. The sensors should be placed at plant level in the greenhouse. Climate in the greenhouse is controlled by:

- $\quad$ heating system

- $\quad$ ventilation and fogging system

- $\quad$ lighting and shading system

- fertigation system

- $\quad$ CO2 injection system

\section{OPERATING PRINCIPLE}

Numerous applications of a control system have significantly increased through the development of new materials for highly efficient actuation and sensing, thereby reducing energy losses and environmental impacts [4]. An automatic control system includes sensors, PLC and actuators. The algorithm for automatic control of the greenhouse microclimate includes several steps:

1. The sensor detects the level of climate parameter and sends a signal to the PLC.

2. The PLC checks whether it is in the range or not (above or below).

3 . When the measured value is above the maximal or below the minimal preset value the PLC performs action. It runs the actuators until the climatic parameter is brought back to its optimum.

\subsection{Heating system}

Heating water system could be based upon the perimetric pipelines, under benches, or by overhead fanradiators [5]. A hot water heating system is the best way to provide uniform temperature distribution in the greenhouse [6]. The hot water heating system includes:

- boiler with a burner

- main heating loop

- $\quad$ secondary heating loops

The burner heats the water in the boiler, which then flows through the main heating loop. The hot water is pumped through the secondary heating loops and tubing 
system which is located between plants, along the side walls and under the roof.



Figure 1. Hot water circulation pump and three-way mixing valve (1- hot water from the boiler,2- hot water to the pipes, 3- cooled water)

A thermohygrometer placed in the greenhouse detects ambient temperature. It also sends a signal to the PLC. The PLC then calculates the necessary hot water temperature in the boiler and pipe system, based on difference between the detected and desired (set) optimal temperature [7].

The temperature on the pipeline surface is measured within 1-1.5 $\mathrm{m}$ after mixing valve [8]. The water temperature in the system is controlled to maintain the desired greenhouse temperature, by using three-way mixing valves and mixing hot and cold water at a constant flow rate. The PLC controls valve operating, in the sense of open and close cycles. The PLC does not measure deflector position in the valve (no position feedback). Water pumps (high flow rate /low pressure) are also controlled by the PLC. The main circulation pump runs constantly (high/low/off), maintaining more uniform temperature field. The (on/off) circulation pumps are applied in the secondary heating sections in order to reduce energy consumption.

\subsection{Ventilation and fogging system}

Greenhouse ventilation is most important for controlling the temperature, relative humidity and $\mathrm{CO}_{2}$ level. A good ventilation in the greenhouse can be achieved with a combination of a roof vent, front doors and fans [9]. Plants grow under the influence of the PAR radiation (diurnal conditions), performing the photosynthesis process. Furthermore, temperature influences the speed of sugar production by photosynthesis, and thus radiation and temperature have to be in balance in the way that a higher radiation level corresponds to a higher temperature [10]. In the case of high temperature and relative humidity (thermohygrometer) or $\mathrm{CO}_{2}$ concentration (carbon dioxide sensor) in the greenhouse, the PLC activates the electric motors and roof vent opens for $10 \%$. The best is to use butterfly roof vent where one of each side can be automatically opened, depending on the wind direction [11].

Based on the difference rate between detected and preset temperature, as well as relative humidity and CO2 level, PLC calculates optimal roof vent position. Just a while after (usually 3 min.), PLC performs check up and if the control parameter hasn't been brought back to its optimal level, the roof vent keeps opening for another $10 \%$.

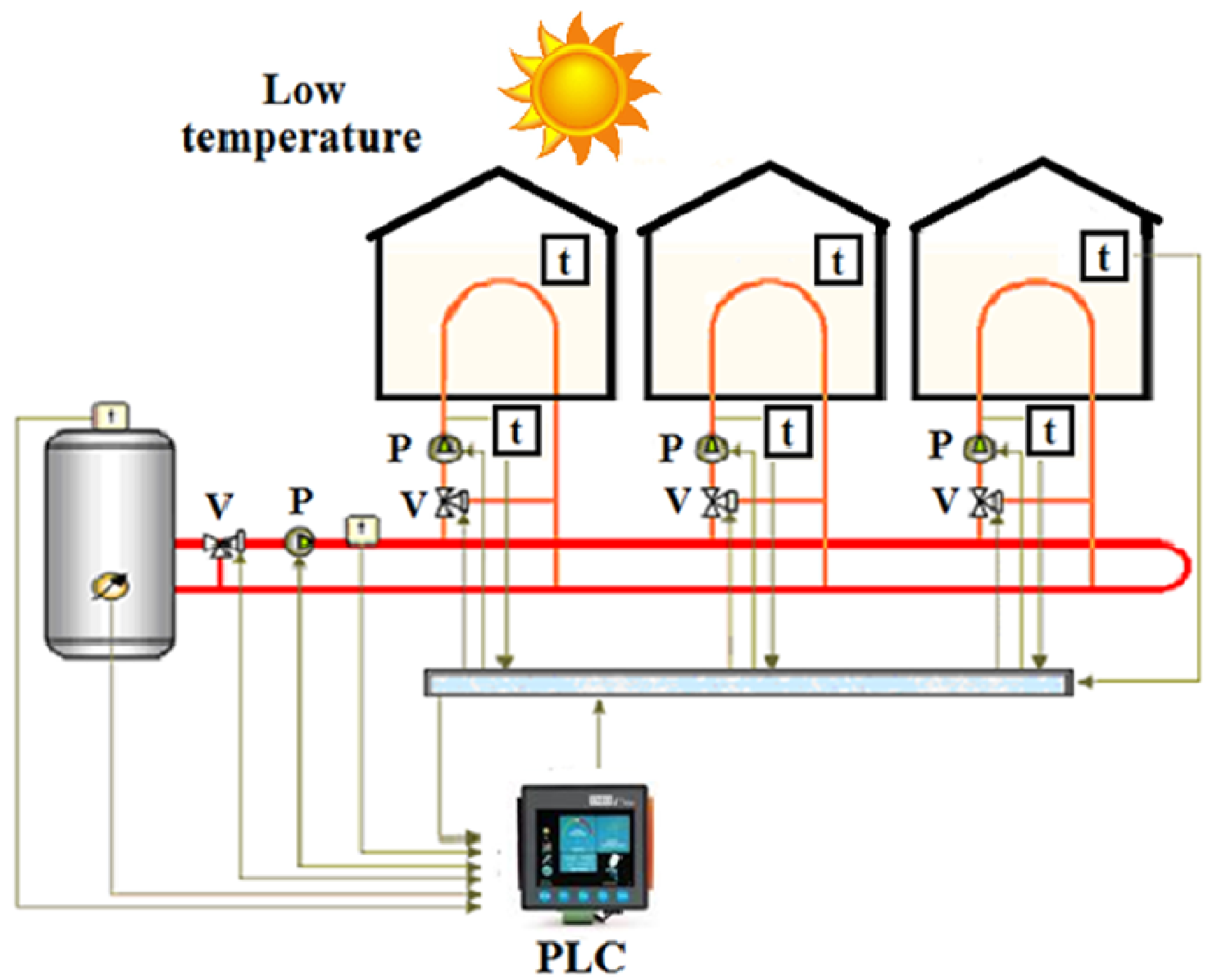

Figure 2. Heating system configuration 


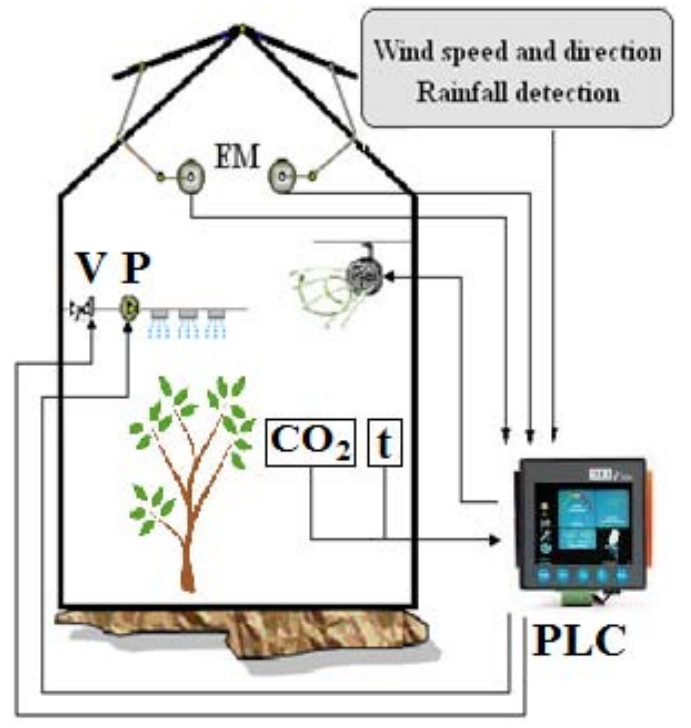

Figure 3. Ventilation and fogging system

This process continues until the parameter does not drop below the maximum allowable value.

If the weather station detects rainfall or high wind, the PLC closes the roof vent and runs the fans or fogging system. The role of the fans is to maintain the uniform temperature and humidity field. The fresh air enters at one side and replaces hot stale air that moves out at the opposite side of the greenhouse. The fans induce the air flow and raise the hot air up. The operating principle is the same, the PLC calculates the time needed for fans to run and activates its electric motor.

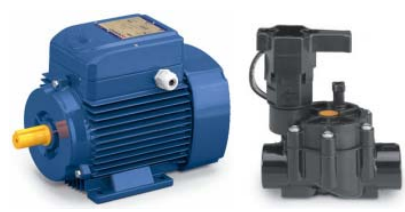

Figure 4. Single-phase asynchronous motor (0,95-4,08 HP) and solenoid valve (low flow, high pressure)

Fogging system consists of a set of micro sprinklers that release water under the high pressure and create a fine spray, which increases ambient humidity and lowers the temperature. Mist flow is varied by solenoid valves which are controlled by the PLC. High pressure pumps driven by single-phase motors run continually (on/off), also controlled by the PLC [12].

\subsection{The lighting system}

Light intensity significantly influences other climate parameters in the greenhouse. Artificial illumination is applied in the absence of natural light, or when overshaded. The shading system is installed mostly to prevent heat transfer from excessive light (blocking the direct sun rays). Shade curtains also help to reduce thermal losses at night. If the weather station detects high solar radiation, the PLC activates the electric motors (roll-up system) and curtains move horizontally.

The difference between the detected and desired solar radiation, initiates the PLC to calculate the necessary change of the curtain position. Special lamps are used to provide enough light for a normal crops growth (during winter and cloudy days). The lack of natural light, directs the PLC to turn the lights on [13]. The PLC can calculate the required illuminating time based on the growing season of crop, in order to determine the amount of light needed for the process of photosynthesis [14].

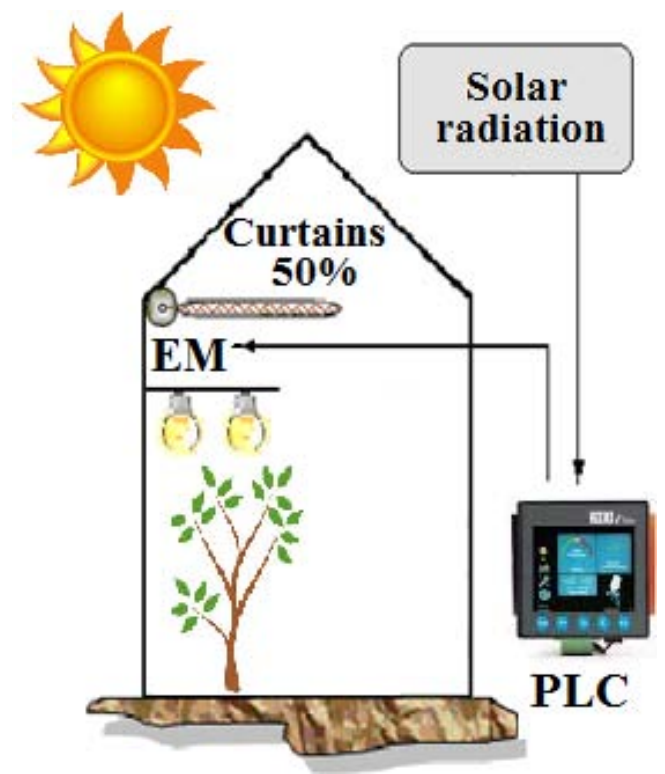

Figure 5. Lighting and shading system

\subsection{Irrigation and nutrition system}

To achieve a rational use of water and fertilizer it's best to use a fertigation system (drip irrigation), which involves the pumps, filters, control panel, EC and $\mathrm{pH}$ sensor [15]. This system provides the required mixture based on current needs of the crops. The EC sensor measures water conductivity and checks the concentration of respective mixture components. The PLC receives a signal from the WET sensor which detects three soil parameters: water content (soil moisture), electrical conductivity and temperature. Based on the quoted information and considering solar radiation and growing crops season, the PLC calculates the required amount of water and fertilizer. Fertilizer is injected and dosed directly into the water by a piston pump. That mixture flows through pipelines propelled by the circulation pumps. The mixture flow can be modified by solenoid valves governed by the PLC.

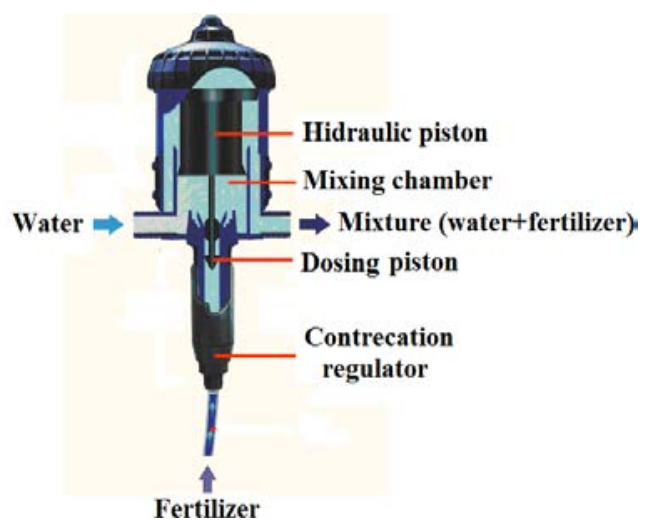

Figure 6. Piston pump 


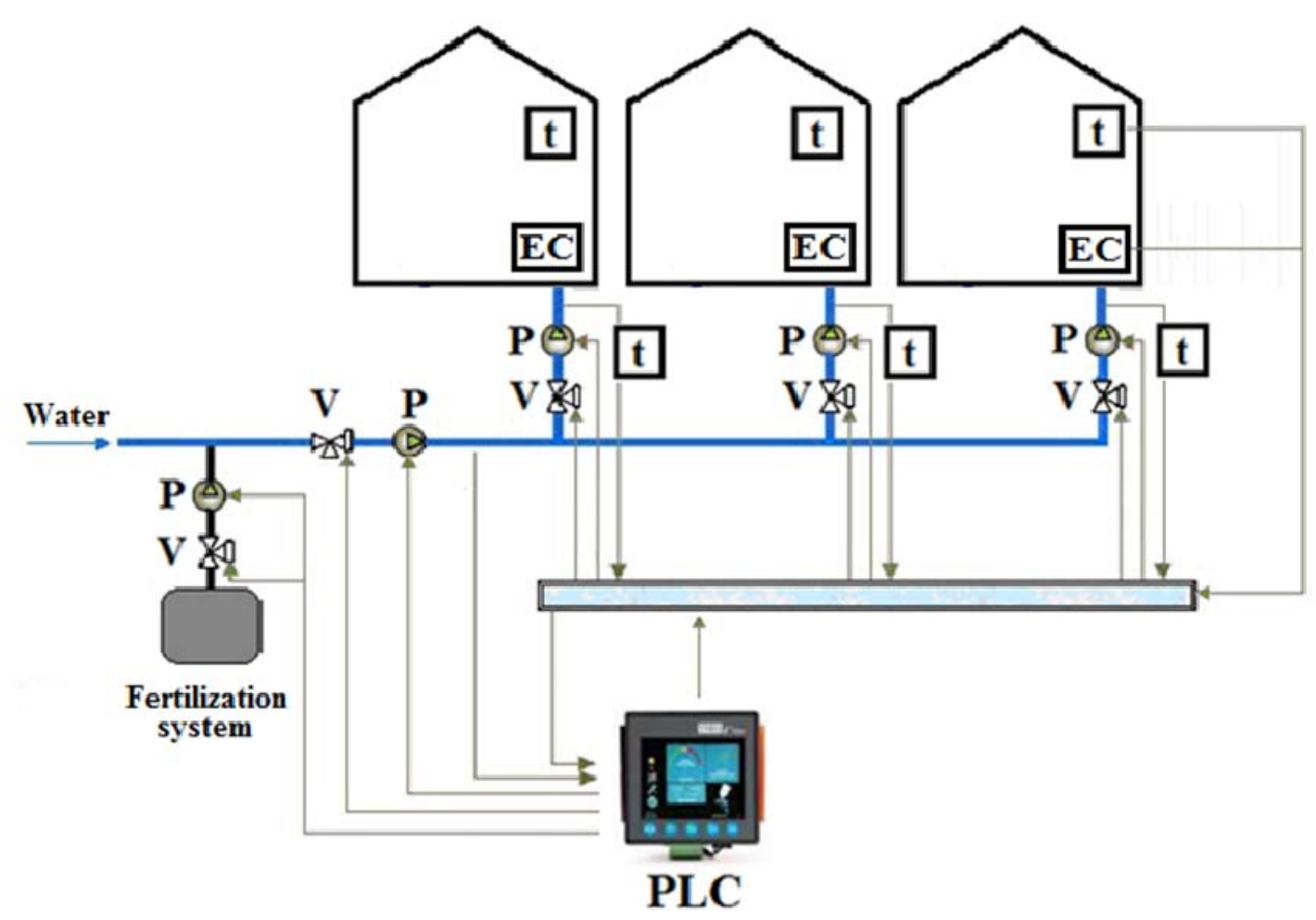

Figure 7. Fertigation system



Figure 8. CO2 injection system

\section{$2.5 \mathrm{CO}_{2}$ injection system}

CO2 is added to the room to improve the process of photosynthesis. Since this paper reviews hot water heating system, assuming that the water will be heated using natural gas, it would be the best to extract $\mathrm{CO} 2$ from combustion byproducts (CO2 and steam). A special fan pushes CO2 from the vent, forcing it to mix with outside air in order to cool down (from $200{ }^{\circ} \mathrm{C}$ ), to the ambient temperature or below it $\left(30^{\circ} \mathrm{C}\right)$ [16]. Gas condenser, collects the steam in the gas pipeline and separates it. A certain portion of the condensing heat can additionally warm up the soil.

A better CO2 distribution within the greenhouse, can be accomplished with a pipeline network, similar to the irrigation/fertigation system. Special gauges for CO2 concentration measurement are set on the distribution pipes, in order to detect possible gases hazard. If the carbon dioxide concentration is below the recommended value, PLC opens solenoid valves starts to run out. After a while the gas check up is performed in order to prevent rapid increasing in $\mathrm{CO} 2$ concentration [17]. 


\section{CONCLUSION}

Implementation of such an effective mechatronic system could be affordable only with large greenhouses. Its profitability rises with the growing size of the land covered. Even smaller greenhouses can absorb such a sophisticated system if the monitoring concept is based on the centralized main unit and distributed local boxes and sensoring in the neighboring assets. Each separate greenhouse is covered with belonging PLC, and then the set of PLCs constitutes a distributed monitoring system with a single governing main unit. This way, a set of different plants can be grown in separate sections and yet a micro-climate would be uniquely managed.

\section{REFERENCES}

[1] Lala, H.R., Nacer, K. M. and Jean-Francois B.: Micro-climate optimal control for an experimental Greenhouse Automation.

[2] Bot, G.P.A: Greenhouse climate from physical processes to a dynamic mode, $\mathrm{PhD}$ thesis, Agricultural University of Wageningen: The Netherlands, 1983.

[3] Momirović, N., Vasić, B., Raičević, D. and Oljača M.: Technical systems for microclimate control in greenhouses, Agricultural Engineering, Faculty of Agriculture, Universities in Belgrade, Institute of Agricultural Engineering, No.4, 2007.

[4] Farid, G. and Benjamin, C.K.: Automatic Control Systems, $9^{\text {th }}$ edition, John Wiley \& Sons, 2010.

[5] Buffington, D.E., Bucklin, R.A., Henley, R.W. and McConnell, D.B.: Heating Greenhouses, document AE11, Institute of Food and Agricultural Sciences, University of Florida, published in 1983 and revised in 1992, Reviewed July 2002, April 2010, and January 2013.

[6] Okada: The Heating Load of Greenhouses, Heat Transmission in the Greenhouse with Pipe Heating Systems, Acta Horticulturne, Acta Horticulturne, 1978.

[7] Chalabi, S., Bailey, J. and Wilkinson, J.: A realtime optimal control algorithm for greenhouse heating, Computers and Electronics in Agriculture, Vol. 15, No. 1, pp. 1-13 1996.

[8] Roberts, J: Soil Heating Systems for Greenhouse Production, Cooperative Extension Publication, E208, Department of Bioresource Engineering, The State University of New Jersey, New Brunswick, 1996.

[9] Hellickson, A. and Walker J: Ventilation of Agricultural Structures, ASAE, St. Joseph, MI, 1983.

[10] Pawlowski, A., Guzman, R.F, Berenguel, M., Sánchez, J. and Dormido S.: Simulation of Greenhouse Climate Monitoring and Control with Wireless Sensor Network and Event-Based Control, MDPI, Switzerland, 2009.
[11]Boulard, T. and Baille, A.: Modelling of Air Exchange Rate in a Greenhouse Equipped with Continuous Roof Vents, Journal of Agricultural Engineering Research, Vol. 61, No. 1, pp. 37-47, 1995.

[12] Montero, J.I., Anton, A., Biel, C. and Franquet, A.: Cooling of greenhouses with compressed air fogging nozzles, Acta horticulturae, pp. 199-210, 1990.

[13] Moe, R. and Grimstad, S.O. and Gislerod, H.R.: The use of artificial light in year round production of greenhouse crops in norway. Acta horticulturae, pp.35-42, 2006.

[14] Mortensen, L.M. and Strømme, E.: Effects of light quality on some greenhouse crops, Scientia Horticulturae, Vol. 33, No. 1-2, Pages 27-36, 1987.

[15] Hao, L., Ai-wang, D., Fu-sheng L., Jing-sheng S. and Yan-Cong, W. and Chi-Tao, S.: Drip Irrigation Scheduling for Tomato Grown in Solar Greenhouse Based on Pan Evaporation in North China Plain, Journal of Integrative Agriculture, Vol. 12, No. 3, pp. 520-531, 2013.

[16] Holloway, S., Karimjee, A., Makoto, A., Pipatti, R., and Rypdal, K: Guidelines for National Greenhouse Gas Inventories, Chapter 5 (Carbon Dioxide Transport, Injection and Geological Storage), IPCC, 2006.

[17] Kläring, H.-P., Hauschild, C., Heißner, A. and BarYosef, B.: Model-based control of $\mathrm{CO}_{2}$ concentration in greenhouses at ambient levels increases cucumber yield, Agricultural and Forest Meteorology, Vol. 143, No. 3-4, pp.208-216, 2007.

\section{КОНТРОЛА МИКРО КЛИМЕ У ПЛАСТЕНИЦИМА}

\section{Немања Радојевић, Данка Костадиновић, Христина Влајковић, Емил Вег}

Основни циљ контроле микроклиме у пласеницима је постизање оптималних услова за раст и развој усева. Узимајући у обзир сложеност овог процеса, прекомерна котрлола микроклиме може неповољно утицати на развој усева. Шта више, потребна нам је оптимална контрола како би остварили ове циљеве, укључујући ниске трошкове производње и ниску емисију штетних гасова. У овом раду, описан је један практичан начин за конструкцију савременог система у пластенику. Систем за контролу, при регулацији микроклиме, узима у обзир вредност унутрашњих и спољашњих климатских параметара. Контролна јединица очитава податке са сензора и у складу са захтеваним климатским условима у пластеницима, спроводи одређену акцију на извршним уређајима. Формирање контролног алгоритма је у овом случају сложен процес, због међусобног утицаја климатских променљивих у пластеницима. 